\title{
Lip and Oral Cavity Cancer pMX TNM Finding v6
}

National Cancer Institute

\section{Source}

National Cancer Institute. Lip and Oral Cavity Cancer pMX TNM Finding v6. NCI

Thesaurus. Code C64427.

Lip and oral cavity cancer in which distant metastasis cannot be assessed. (from AJCC 6th Ed.) 